\title{
Pengaruh Mata Kuliah Kewirausahaan Terhadap Minat Berwirausaha Pada Mahasiswa Pendidikan Ekonomi
}

\author{
Bella Nova Dhira ${ }^{1}$, Rinto Alexandro², Windy Utami Putri ${ }^{3}$ \\ Pendidikan Ekonomi, FKIP Universitas Palangka Raya \\ *Corres pondence author: windyutamiputri@upr.co.id Tel.:+6282240950594
}

\begin{abstract}
The Economic Education Study Program at the University of Palangka Raya is one of themajors that has implemented entrepreneurship education. Entrepreneurship education has beenincludedinthecurriculum and has become a compulsory subject for economic education students. The purpose of this study was to determine whether there was an effect of entrepreneurs hip courses on the interest of students of Economic Education Class of 2017 at the Uni versity of Palangka Raya and to determine th e interestinentrepreneurshipof students of Economic Education of Class of 2017 at the University of Palangka Raya.Inconductingthis research, quantitative methods were used, while da ta collection was carried out by a nalyzing data and submitting a questionnaire/questionnaire to Economic Education students class 2017 at theUniversityofPalangka Raya.The population in this study were students of economic education class 2017 at theUniversityofPalangka Raya and the sample used was total sampling where all members/elements of the population were inves tigated. The validity test was carried out through the calculation of SPSS for windows while the reliability test used the Cronbach's alpha formula. The da ta analysis technique used (1) validity and reliability tests, (2) hypothesis testing, namely (a) simple linear regression, (b) partial t-test, and (c) coefficient of determination $\mathrm{R}^{\wedge} 2$. Fromthe results of the Si mple Linear Regression Test, $Y=18.689+0.677 . X$, with the coefficient of determinationorKP: 0.370 , it means that the entrepreneurs hip course va riable contributes to the interest in entrepreneurship(Y)by $37 \%$. While the remaining $63 \%$ is influenced by other factors outs ide the variables inthestudy. Theresults ofthe $\mathrm{t}$-value test show that the t_count value is $4.529>\mathrm{t}$ ta ble, which is 2.03011 with a significantlevel of0.000.The significant level is smaller than 0.05 which means that the hypothesis in this study rejects Hoandaccepts Ha. Thus it can mean that the hypothesis "entrepreneurship courses have a di rect and significantpositiveeffecton students' interest in entrepreneurship" is accepted.
\end{abstract}

Keywords: Entrepreneurship Course, Interest in Entrepreneurship

\begin{abstract}
Abstrak: Program Studi Pendidikan Ekonomi Universitas Palangka Raya merupakansalahsatujurusanyangsudah menerapkan pendidikan kewirausahaan. Pendidikan kewirausahaan telah masuk kedalam kurikulumdan menjadi mata kuliah wajib bagi mahasiswa pendidikan ekonomi. Tujuanpenelitianiniadalahuntukmengetahui apakah a da penga ruh ma ta kuliah kewirausahaan terhadap minat mahasis wa PendidikanEkonomi Angkatan 2017 Universitas Palangka Raya dan untuk mengeta hui minat berwira us aha ma hasiswa PendidikanEkonomi Angkatan 2017 Universitas Palangka Raya. Dalam melakukan penelitian ini menggunakanmetodekuantitatif, sedangkan pengumpulan da ta dilakukan dengan a nalisis data dan mengajukan angket/kuesioner kepa da mahasiswa Pendidikan Ekonomi angkatan 2017 di Universitas Palan gka Raya. Populasi dalampenelitianini adala h ma hasiswa pendidikan ekonomi angkatan 2017 di Universitas Palangka Raya dansampel yangdigunakan adala h total sampling di ma na sel uruh anggota/elemen populasi yang dis el idiki.Uji validitas dilakukanmelalui perhitungan SPSS for windows sedangkan uji reliabilitas menggunakan rumus cronbach'salpha.Teknikanalisis data menggunakan (1) uji validitas dan reliabilitas, (2) Uji Hipotesis yai tu (a) regresi linearsederhana,(b)Uji T parsial, dan (c) koefisiensi determinasi $\boldsymbol{R}^{2}$. Dari hasil Uji Regresi Linear Sederhana mengha silkanY=18,689+ 0,677 . X, dengan nilai koefisien determinasi ata KP :0,370 artinya variabel mata kuliah kewirausahaan memberikan kontribusi terhadap minat berwirausaha $(Y)$ s ebes ar 37\%.Sedangkansisanya 63\%dipengaruhi oleh faktor lain diluar variabel dala m penelitian. Hasil pengujian nilai t, menunjukkannilait hitungsebesar 4,529> t_tabel yaitu sebesar 2.03011 denga n taraf signifikan 0,000. Taraf signifikan ters ebutlebihkecil dari 0,05yang berarti bahwa hipotesis dalam penelitian ini menolak Ho dan menerima Ha. Dengan demi kian dapatberarti
\end{abstract}


bahwa hipotesis "mata kuliah kewirausahaan secara positif berpengaruhlangsungdansignifikanterhadapminat berwirausaha mahasiswa" diterima.

Kata Kunci : Mata Kuliah Kewirausahaan, Minat Berwirausaha

\section{Pendahuluan}

Banyak orang bermimpi kelak setelah lulus dari perguruan tinggi berkeinginan menjadi seorang pegawai dengan gaji tetap yang diterimanya tiap bulan, sehingga dengan menjadi pegawai seakan hidupnya sudah terjamin, hal ini sering dijumpai di berbagai tempat, dengan menjamurnya pelamar kerja pada saat diumumkannya suatu lowongan pekerjaan. Bahkan lulusan perguruan tinggi semakin menambah pencari kerja. Oleh sebab itu semua pihak harus terus berpikir dan mewujudkan karya nyata dalam mengatasi kesenjangan antara lapangan kerja dengan lulusan institusi pendidikan. Kesenjangan ini merupakan penyebab utama peningkatan angka pengangguran. Sedangkan pengangguran adalah salah satu permasalahan pembangunan yang sangat kritis khususnya di Negara Indonesia.Salah satu solusinya adalah dengan mencetak lulusan lembaga pendidikan yang memiliki potensi untuk mengembangkan keterampilannya membuat usaha mandiri. Selain menjadi solusi bagi dirinya, seringkali usaha mandiri ini mendatangkan berkah bagi orang lain yang direkrut sebagai karyawan ataupun buruh pada usaha yang dirintisnya. Badan Pusat Statistik (BPS) mencatat jumlah pengangguran per Februari 2020 mencapai 6,88 juta orang. Jumlah ini naik 0,06 juta atau 60 ribu orang dibandingkan Februari 2019 secara year on year (yoy). "Tingkat pengangguran terbuka Februari 2020 agak flat turun tipis dari 5,01 persen menjadi 4,99 persen," ucap Kepala BPS Suhariyanto dalam siaran live di akun Youtube BPS, Selasa (5/5/2020). Naiknya angka pengangguran ini terjadi seiring peningkatan angkatan kerja Indonesia per Februari 2020 yang mencapai 137,91 juta orang atau naik 1,73 juta orang. Dari angka itu, jumlah orang yang bekerja naik 1,67 orang menjadi 131,03 juta orang di kuartal I 2020. Meski jumlah orang yang bekerja lebih banyak, tingkat partisipasi angkatan kerja (TPAK) ternyata tetap turun. Pada Februari 2019 angkanya mencapai 69,32 persen dan turun 0,15 poin persen pada Februari 2020 menjadi hanya 69,17 persen. Pemerintah masih menghadapi persoalan tingginya angka pengangguran terdidik. Hal ini tercermin dari tingkat pengangguran terbuka (TPT) lulusan universitas dengan rentang pendidikan S1 hingga S3 yang mencapai 737.000 orang. Berdasarkan data Badan Pusat Statistik (BPS), per Agustus 2019, jumlah pengangguran lulusan universitas mencapai 5,67 persen dari total angkatan kerja sekitar 13 juta orang. Meski persentasenya turun dibandingkan Agustus 2018 yang 5,89 persen, angkanya di atas rata-rata pengangguran nasional yang sebesar 5,28 persen. Berbagai strategi diterapkan oleh pemerintah untuk meningkatkan jumlah wirausahawan di Indonesia, salah satunya ialah dengan memasukkan mata kuliah Kewirausahaan ke dalam kurikulum pendidikan, khususnya pendidikan di tingkat perguruan tinggi. Universitas Palangka Raya merupakan salah satu institusi pendidikan yang ikut menerapkan kurikulum tersebut dimana mata kuliah Kewirausahaan tersebut. Perguruan tinggi seharusnya tidak lagi hanya mengutamakan bagaimana mahasiswa cepat lulus dan mendapat pekerjaan. Tetapi perguruan tinggi harusnya lebih fokus bagaimana lulusan Universitas mampu menciptakan lapangan pekerjaan. Maka untuk itu diperlukan peningkatan intensi wirausaha dikalangan mahasiswa. Intensi wirausaha atau niat kesungguhan untuk berwirausaha harus tertanam dalam benak mahasiswa. Program Studi Pendidikan Ekonomi Universitas Palangka Raya merupakan salah satu jurusan yang sudah menerapkan pendidikan kewirausahaan. Pendidikan kewirausahaan telah masuk kedalam kurikulum dan menjadi mata kuliah wajib bagi mahasiswa jurusan pendidikan ekonomi. Mata kuliah kewirausahaan ditempuh pada semester enam. Mata kuliah tersebut diterapkan berupa teori dan praktek berwirausaha. Pendidikan kewirausahaan yang berupa teori diberikan di dalam kelas untuk pembekalan sebelum mahasiswa terjun menjadi wirausaha, sedangkan dalam praktek berwirausaha melalui kegiatan mendirikan perusahaan-perusahaan kecil yang dikelola oleh mahasiswa sesuai dengan kelompoknya. 
Berdasarkan pengamatan dan hasil wawacara kepada mahasiswa Pendidikan Ekonomi khususnya mahasiswa pada angkatan 2017 di Universitas Palangka Raya yang berjumlah sebanyak 50 mahasiswa, fenomena yang terjadi pada mahasiswa angkatan 2017 ada yang berhasil dalam mengembangkan jenis usahanya dari usaha besar, usaha menengah dan usah kecil dan ada juga yang kurang berhasil dalam menjalankan usaha yang dibuat oleh mahasiswa itu sendiri, jadi hasil mini research yang telah dilakukan kepada 10 mahasiswa Pendidikan Ekonomi angkatan 2017 yang telah mengikuti mata kuliah kewirausahaan yaitu, hanya 3 mahasiswa yang berminat mencoba berwirausaha setelah mengikuti mata kuliah kewirausahaan. Sedangkan 3 mahasiswa mempunyai keinginan untuk berwirausaha dan 4 mahasiswa lainnya lagi masih ragu berwirausaha, karena dibayangi resiko jika nanti tidak berhasil. Apabila mahasiswa mengetahui manfaat berwirausaha, yaitu mereka dapat menciptakan lapangan pekerjaan bagi orang lain dan menghasilkan pendapatan yang besar dari seorang karyawan/menjadi PNS. Berdasarkan dijelaskan di atas, peneliti berinisiatif melakukan penelitian lebih lanjut untuk mengetahui minat berwirausaha mahasiswa setelah mengikuti mata kuliah kewirausahaan apakah ada keterkaitan mata kuliah kewirausa haan terhadap minat berwirausaha pada mahasiswa maka penulis tertarik untuk melakukan penelitian.

\section{Metode}

Mengingat metode penelitian adalah usaha untuk menemukan, mengembangkan dan menguji kebenaran suatu pengetahuan dalam upaya memecahkan suatu permasalahan yang ada. Pendekatan penelitian yang digunakan dalam penelitian ini adalah pendekatan kuantitatif. Dengan pendekatan yang digunakan adalah pendekatan kuantitatif yaitu pendekatan yang memungkinkan dilakukan pencatatan dan analisis data hasil penelitian menggunakan perhitungan statitistik: Menurut Sugiyono (2018:8) "Metode penelitian kuantitatif dapat diartikan sebagai metode penelitian yang berlandaskan pada filsafat positivisme, digunakan untuk meniliti pada populasi atau sampel tertentu, pengumpulan data menggunakan instrumen penelitian, analisis dan bersifat kuantitatif/statistik, dengan tujuan untuk menguji hipotesis yang telah diterapkan". Penelitian ini menggunakan pendekatan penelitian kuantitatif dengan jenis penelitian deskriptif. Dikarenakan penelitian ini bertujuan untuk mengetahui ada tidaknya pengaruh dan jika terdapat pengaruh seberapa besar pengaruh variabel bebas, yaitu mata kuliah kewirausahaan $(X)$ terhadap minat berwirausaha $(Y)$. Penelitian ini mengambil lokasi di wilayah kampus Universitas Palangka Raya tepatnya di Gedung P, Program Studi Pendidikan Ekonomi Fakultas Keguruan dan IImu Pendidikan. Lokasi tersebut layak di jadikan lokasi penelitian karena peneliti ingin mengetahui apakah ada Pengaruh Mata Kuliah Kewirausahaan Terhadap Minat Berwirausaha Pada Mahasiswa Pendidikan Ekonomi Angkatan 2017 Di Universitas Palangka Raya. Populasi dan sampel dalam penelitian maka yang akan menjadi populasi dalam penelitian ini adalah mahasiswa Program Studi Pendidikan Ekonomi Angkatan 2017 di Universitas Palangka Raya dengan jumlah 37 mahasiswa yang telah mengikuti matakuliah kewirausahaan. Dalam penentuan sampel digunakan teknik pengambilan sampel yaitu dengan mengambil seluruh total sampel yang telah ditetapkan yaitu sebanyak 37 mahasiswa. Jadi besarnya jumlah populasi sampel sama dengan besarnya jumlah populasi yaitu sebanyak 37 orang. Dalam penelitian ini instrumen yang digunakan berupa kuesioner, yang terdiri atas pernyataan yang dirancang untuk mengukur variabel Mata Kuliah (X) dan variabel minat berwirausaha (Y). Angket ini menggunakan skala Likert. Menurut Sugiyono : Sugiyono $(2018,94)$ Skala Likert digunakan untuk mengukur sikap, pendapat, dan presepsi seseorang atau sekelompok orang tentang fenomena sosial. Masing - masing item dibuat dengan skala 1-4 kategori jawaban, setiap jawaban diberi skor atau bobot yaitu banyaknya 1 sampai 4. Uji validitas digunakan untuk mengukur sah atau valid tidaknya suatu kuesioner. Sugiyono (2018:267), mengatakan bahwa: "validitas merupakan derajat ketepatan antara data yang terjadi pada obyek penelitian dengan daya yang dapat dilaporkan oleh peneliti". Dengan demikian data yang valid adalah data "yang berbeda" antar data yang dilaporkan oleh peneliti dengan data yang sesungguhnya terjadi pada obyek penelitian. Tujuan dari pengujian validitas ini adalah untuk mengetahui kelayakan kuesioner untuk dijadikan instrumen penelitian. Reliabilitas menunjukan pada suatu pengertian bahwa suatu instrumen cukup dapat dipercaya untuk digunakan sebagai alat pengumpul data. Untuk menghitung 
uji reliabilitas pada penelitian ini dilakukan dengan program SPSS deng an teknik Alpha Cronbach. Data penelitian ini akan dianalisis secara simultan dengan menggunakan analisis regeresi linear sederhana. Uji linieritas dilakukankan untuk mengetahui apakah variabel bebas memiliki lineritas terhadap variabel terikat. Uji ini biasanya digunakan sebagai prasyarat dalam analisis korelasi atau regresi. Pengujian ini dilakukan dengan menggunakan Test For Linearity pada taraf signifikan 0,05 . Kedua variabel dikatakan mempunyai hubungan linier apabila nilai signifikansi $>0,05$. Uji linieritas dilakuakn dengan bantuan komputer program SPSS 23 For Windows. Pengujian hipotesis dilakukan dengan metode regresi linier sederhana. Regresi linier sederhana digunakan untuk menguji sejauh mana hubungan sebab akibat antara variabel independen $(\mathrm{X})$ terhadap variabel dependen $(\mathrm{Y})$. Uji hipotesis dalam penelitian ini menggunakan metode regresi dengan bantuan komputer program SPSS 23 For Windows. Selanjutnya untuk mengetahui seberapa besar pengaruh mata kuliah kewirausahaan (X) terhadap minat berwirausaha $(Y)$, maka dilakuakan alanalisis koefisien determinasi $R$ Square (R2). Analisis koefisien determinasi R Square (R2) dalam penelitian ini menggunakan bantuan komputer program SPSS 24 For Windows. Hasil analisis yang diperoleh akan dibandingkan dengan kriteria koefisien.

\section{HASIL DAN PEMBAHASAN}

Ringkasan hasil dari analisis data dapat dilihat dari tabel-tabel di bawah ini :

\section{a) Regresi Linear Sederhana}

Regresi linear sederhana digunakan untuk melihat pengaruh Mata Kuliah Kewirausahaan (X) terhadap Minat Berwirausaha (Y) di Program Studi Pendidikan Ekonomi Angkatan 2017 Universitas Palangka Raya.

Tabel 1. Regresi Linear Sederhana Mata Kuliah Kewirausahaan

\begin{tabular}{|c|c|c|c|c|c|c|}
\hline \multicolumn{7}{|c|}{ Coefficients $^{\mathrm{a}}$} \\
\hline \multirow[t]{2}{*}{ Model } & & \multicolumn{2}{|c|}{$\begin{array}{l}\text { Unstandardized } \\
\text { Coefficients }\end{array}$} & \multirow{2}{*}{$\begin{array}{c}\text { Standardized } \\
\text { Coefficients } \\
\text { Beta }\end{array}$} & \multirow[t]{2}{*}{$\mathrm{T}$} & \multirow[t]{2}{*}{ Sig. } \\
\hline & & $\mathrm{B}$ & Std. Error & & & \\
\hline \multirow[b]{2}{*}{1} & (Constant) & 18,689 & 6,816 & & 2,742 &, 010 \\
\hline & $\begin{array}{l}\text { Mata Kuliah } \\
\text { Kewirausahaan }\end{array}$ & 677 & , 149 & ,608 & 4,529 & ,000 \\
\hline \multicolumn{7}{|c|}{ a. Dependent Variable: Minat Berwirausaha } \\
\hline $\begin{array}{l}\text { Adapt } \\
\mathbf{Y}=\mathbf{a} \\
\mathbf{Y}=\mathbf{1 8}\end{array}$ & $\begin{array}{l}\text { Sumber: data c } \\
\text { In persamaan Reg } \\
\text { b.x } \\
\mathbf{6 8 9}+\mathbf{0 , 6 7 7 . x}\end{array}$ & $\begin{array}{l}2021 \\
\text { inear Sed }\end{array}$ & hana adal & ebagai berikut & & \\
\hline
\end{tabular}

Berdasarkan hasil penelitian menunjukkan bahwa variabel mata kuliah kewirausahaan terhadap variabel minat berwirausaha berpengaruh positif, dapat dibuktikan dengan menunjukkan nilai $t_{\text {hitung }}$ sebesar sebesar 4,529 $>t_{\text {tabel }}$ yaitu sebesar 2.03011 dengan taraf signifikan 0,000. Taraf signifikan tersebut lebih kecil dari 0,05, yang berarti bahwa hipotesis dalam penelitian ini menolak Ho dan menerima $\mathrm{Ha}$ artinya mata kuliah kewirausahaan secara positif berpengaruh langsung dan signifikan terhadap minat berwirausaha. Dengan kemudian dapat disimpulkan bahwa variabel mata kuliah kewitausahaan berpengaruh positif terhadap minat berwirausaha Pendidikan Ekonomi angkatan 2017 di Universitas Palangka Raya. Berdasarkan hasil penelitian nilai koefisien determinasi atau KP $=0,370$ $\left(R^{2} \times 100 \%\right)$ artinya variabel mata kuliah kewirausahaan memberikan kontribusi terhadap minat berwirausaha $(\mathrm{Y})$ sebesar $37 \%$. Sedangkan sisanya $63 \%$ dipengaruhi oleh faktor lain diluar variabel dalam penelitian. Hal ini menunjukkan bahwa mata kuliah kewirausahaan mempunyai pengaruh terhadap minat berwirausaha. Dari hasil pengolahan data kuesioner yang disebarkan melalui google formulir yang diisi sebanyak 37 responden masing-masing memiliki potensi sebagai wirausawan. 
Sebagai bahan penafsiran terhadap tingkat hubungan yang ditemukan Tinggi atau Rendah, maka dapat berpedoman pada ketentuan berikut ini:

Tabel 2. Pedoman Kelas Interval 100

\begin{tabular}{cc}
\hline Interval & Tingkat Hubungan \\
\hline $20-36$ & Sangat Rendah \\
\hline $36-52$ & Rendah \\
\hline $52-68$ & Sedang \\
\hline $68-84$ & Tinggi \\
\hline $84-100$ & Sangat Tinggi \\
\hline
\end{tabular}

Sumber: Sugiyono (2018)

Mata kuliah kewirausahaan mendukung minat mahasiswa menjadi wirausahawan, sebagaimana pada proses pembelajaran mata kuliah kewirausahaan diisi oleh pengetahuan tentang nilai-nilai, semangat, jiwa, sikap dan perilaku agar memiliki pemikiran kewirausahaan, akan mendukung untuk menjadi wirausaha juga menumbuhkan pemikiran dan karakteristik wirausaha dan hal ini mendukung minat mahasiswa untuk berwirausaha. Tapi selain pengetahuan yang di peroleh dari pendidikan formal adapun faktor lain yang mempengaruhi yaitu berupa kemandirian, kreatif dan inovatif seseorang juga. Jika seseorang hanya memperoleh teori-teori tentang kewirausahaan tetapi seseorang tersebut tidak mengembangkan atau mempraktekan langsung di masyarakat maka sama saja dia mencari sesuatu tapi setelah di dapat di biarkan seperti suatu yang tidak berguna. Dengan kemudian dapat disimpulkan bahwa variabel mata kuliah kewirausahaan berpengaruh positif terhdadap minat berwirausaha mahasiswa pendidikan ekonomi angkatan 2017 di Universitas Palangka Raya. Sehingga dapat dikatakan bahwa 37 mahasiswa atau 37\% mahasiswa Pendidikan Ekonomi memiliki minat berwirausaha karena telah mengikuti mata kuliah kewrirausahaan dan 63\% dipengaruhi oleh faktor lain. Begitu juga hasil Uji t secara parsial dimana mata kuliah kewirausahaan berpengaruh positif dan signifikan terhadap minat berwirausaha mahasiswa pendidikan ekonomi angkatan 2017 di Universitas Palangka Raya.

\section{Kesimpulan}

Dari hasil penelitian tentang pengaruh mata kuliah kewirausahaan terhadap minat berwirausaha mahasiswa Pendidikan Ekonomi angkatan 2017 di Universitas Palangka Raya maka dapat ditarik kesimpulan sebagai berikut : Berdasarkan Hasil Uji Regresi Linear Sederhana menghasilkan $Y=18,689$ $+0,677 . X$, dengan nilai koefisien determinasi atau $\mathbf{K P}=0,370\left(R^{2} \times 100 \%\right)$ artinya variabel mata kuliah kewirausahaan memberikan kontribusi terhadap minat berwirausaha $(Y)$ sebesar $37 \%$. Hasil pengujian nilai t, menunjukkan nilai $t_{\text {hitung }}$ sebesar 4,529 $>t_{\text {tabel }}$ yaitu sebesar 2.03011 dengan tarafsignifikan 0,000 . Taraf signifikan tersebut lebih kecil dari 0,05 , yang berarti bahwa hipotesis dalam penelitian ini menolak Ho dan menerima $\mathrm{Ha}$ artinya mata kuliah kewirausa haan secara positif berpengaruh langsung dan signifikan terhadap minat berwirausaha mahasiswa Pendidikan Ekonomi angkatan 2017 di Universitas Palangka Raya.

\section{DAFTAR PUSTAKA}

Ahmad Susanto. 2013. Teori Belajar dan Pembelajaran di Sekolah Dasar.Jakarta: Kencana.

Atmaja, A. T., \& Margunani, M. 2016. Pengaruh Pendidikan Kewirausahaan dan Aktivitas Wirausaha terhadap Minat Berwirausaha Mahasiswa Universitas Negeri Semarang. Economic Education Analysis Journal, 5(3), 774-774.

Alexandro, R., \& Irwansyah, M. R. 2020. Peranan Smkn 3 Dalam Mengembangkan Ekonomi Kreatif Di Kota Palangka Raya. Jurnal Pendidikan Ekonomi Dan Kewirausahaan. Vol. 4, No. 1 Juni 2020, Hal. 145-160. 
Fatrika et al. 2014. Analisis Faktor-Faktor Yang Mempengaruhi Minat Wirausaha Mahasiswa Dengan Teknik SEM. Jurnal Matematika UNAND Vol. 1 No. 2 Hal. 5-12. ISSN 2303.2910.

Fuadi, I.F. 2013. Hubungan minat berwirausaha dengan prestasi praktik kerja industri siswa kelas XII teknik otomotif SMK Negri 1 Adiwerna Kabupaten Tegal." Jurnal PTM 9(1) Desember: 92-98.

Hendro. 2011. Dasar-Dasar Kewirausahaan. Jakarta: Eralangga.

Hidayat, D. 2017. Model Pelatihan Magang Kewirausahaan Potensi Lokal. Seminar Nasional Pendidikan Nonformal FKIP Universitas Bengkulu, Vol 1 Nomor 1.

Ihsana El Khuluqo. 2017. Belajar dan Pembelajaran. Yogyakarta : Pustaka Pelajar

Ismarli Muis, Misnawaty Usman, dkk. Modul Kewirausahaan untuk Mahasiswa. Makassar: Pusat Kewirausahaan Universitas Negeri Makassar, 2015.

Khotimah, N. 2016. Pengaruh Pelatihan Keterampilan Terhadap Minat Berwirausaha Pada Masyarakat Muslim Desa Panca Mukti, Kecamatan Pondok Kelapa, Kabupaten Bengkulu Tengah. Skripsi.

Made Dharmawati, D. Hajah. 2017. Kewirausahaan. Depok: PT Raja Grapindo Persada

M Notoatmodjo, S. 2013. Pengembangan Sumber Daya Manusia Edisi Revisi. Jakarta: PT. Rineka Cipta. Masruroh, F. 2017. Pengaruh Pendidikan Kewirausahaan Terhadap Motivasi Berwirausaha Mahasiswa Departemen Manajemen Fakultas Ekonomi Dan Bisnis Universitas Airlangga Surabaya. Kajian Moral Dan Kewarganegaraan, 5(01).

Sardiman. 2011. Interaksi dan Motivasi Belajar Mengajar, Jakarta: Raja Grafindo Persada.

Setiyono, J. 2020. Upaya Strategi Pengembangan Kewirausahaan Masyarakat Melalui Home Industri Imur Bahalap Kota Palangka Raya. Jurnal Pendidikan IImu Pengetahuan Sosial (JPIPS), 12(1), 6273.

Setiawati, Lilis. 2013. Upaya Optimalisasi Kegiatan Belajar Mengajar, Bandung: PT. Remaja Rosda Karya.

Suherman, Eman. 2010. Desain Pembelajaran Kewirausahaan. Bandung: Alfabeta.

Santoso, Djoko. 2013. Modul Kuliah Kewirausahaan. Jakarta: Direktorat Jenderal Pembelajaran dan Kemahasiswaan Ditjen Pendidikan Tinggi Kementerian Pendidikan dpan Kebudayaan.

Sugiyono. 2018. Metode Penelitian Kuantitatif, kualitatif dan R \& D. Bandung: Alfabeta

Sugiyono. 2018. Metode Penelitian Pendidikan. Bandung. Alfabeta

Suryana. 2014. Kewirausahaan Kiat dan Proses Menuju Sukses. Jakarta: Salemba 4

Slameto. 2013. Belajar dan Faktor-Faktor yang Mempengaruhi. Jakarta : PT Rineka Cipta

Suharsimi Arikunto. 2010. Prosedur Penelitian Suatu Pendekatan Praktik. Jakarata: Rineka Cipta.

Wahyono, Budi. 2014. Pengertian Pendidikan Kewirausahaan. http://www.pendidikanekonomi.com/2014/07/pengertian-pendidikankewirausahaan.html. Diunduh tanggal 23 Juli 2017. 